\title{
First record of Nais schubarti Marcus, 1944 (Oligochaeta: Naididae) in the State of São Paulo
}

\author{
D. A. Girolli ${ }^{*}$, G. R. Gorni ${ }^{a}$, V. Colombo-Corbi ${ }^{a}$ and J. J. Corbi ${ }^{b}$
}

aPrograma de Pós-graduação em Desenvolvimento Territorial e Meio Ambiente, Universidade de Araraquara - UNIARA, CEP 14801-340, Araraquara, SP, Brasil

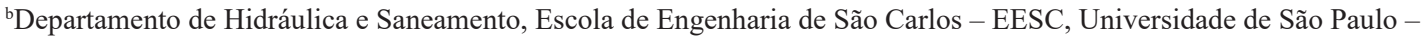
USP, CP 359, CEP 13566-590, São Carlos, SP, Brasil

*e-mail: douglasgirolli@gmail.com

Received: December 13, 2017 - Accepted: May 3, 2018 - Distributed: August 31, 2019

(With 1 figure)

The Oligochaeta (Annelida: Clitellata) is known to have important participation in the aquatic macroinvertebrates fauna, mainly due to its active participation in the organic matter decomposition (Esteves et al., 2011). Despite its ecological importance, the knowledge about this taxon is still incipient (Timm et al., 2001; Gorni et al., 2015).

According to Alves et al. (2008), Petsch et al. (2015), Maroneze et al. (2011) and Ragonha et al. (2014), these organisms can be found living on sandy substrates or in organic matter enriched environments (Behrend et al., 2012). In addition, these organisms are also recorded associated with aquatic macrophytes and leaf litter (Trivinho-Strixino et al., 2000; Alves and Gorni, 2007; Gorni and Alves, 2007; Oliveira et al., 2014) with sponges (Gorni and Alves, 2008) gastropods (Gorni and Alves, 2006), insect larvae (Corbi et al., 2004) and amphibians (Oda et al., 2015). Recent studies (Gorni et al., 2015) recorded 75 species of aquatic oligochaetes in the State of São Paulo, in which 64 species $(85 \%)$ belong to the Naididae family. This family stands out as diverse and abundant, being composed of eight subfamilies totalizing about $50 \%$ of the oligofauna described on the Earth. (Rodriguez and Reynoldson, 2011). In this article, we report the first record of Nais schubarti Marcus 1944 for the State of São Paulo (Figure 1). Sediment samples were collected by the Water Communities Sector (ELHC) of CETESB, and are part of the Sediment Quality Monitoring Network Project.

The specimens were collected in the Paiva Castro reservoir, in the municipality of Franco da Rocha / SP (2321'13"S and 46 $39^{\circ}$ '56"O). The procedures for sampling, fixation and preparation of the samples followed the Technical Standard CETESB L5.309 (CETESB, 2003). The species was identified using the taxonomic criteria adopted by Brinkhurst and Jamieson (1971), Righi (1984) and Brinkhurst and Marchese (1989). According to the authors, $N$. schubarti is described with the following characteristics: length $2.5 \mathrm{~mm}$, diameter of $150 \mu \mathrm{m}$ with twenty-five segments. The species has ventral setae of II-V, 3-5 per tuft, proximal nodule, distal tooth 2 times longer than proximal; in the following three segments by tuft, distal nodule, teeth of similar length. Dorsal bristles, 1 capillary and 1 acicular spatuliform in the distal third.
Bulbiform stomach in VIII segment. Intestine dilated in the $\mathrm{X}$ segment.

In the present literature, $N$. schubarti occurrence records in Brazil were limited to two Brazilian states: Pernambuco (Marcus, 1944; Righi, 1984; Christoffersen, 2007), and Paraná (Montanholi-Martins and Takeda, 2001; Christoffersen, 2007); being recognized as an endemic species of South America (Christoffersen, 2007). However, it is probable that $N$. schubarti occurs in other Brazilian aquatic ecosystems, due to the scarcity of studies that aim at the survey of oligochaete species in Brazilian aquatic ecosystems, as well as the lack of specialists in the taxonomic identification of these worms.

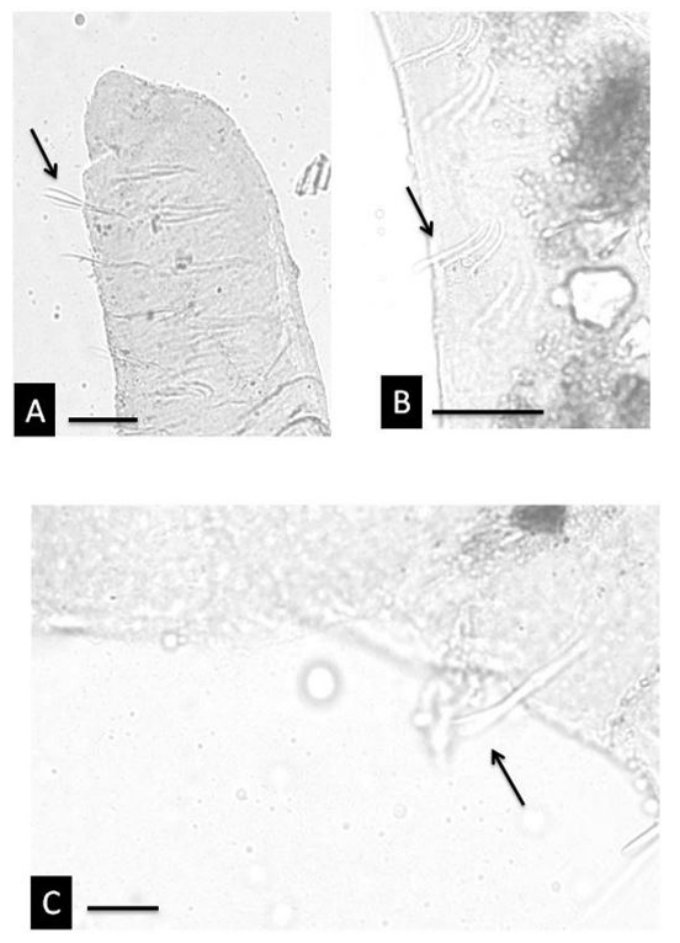

Figure 1. Nais schubarti. (A) Prostomium and anterior ventral chaetae (detail); (B) Posterior ventral chaetae; and (C) Dorsal chaetae (detail). Scale bars: (A) and (B) $50 \mu \mathrm{m}$; (C) $10 \mu \mathrm{m}$. 


\section{Acknowledgements}

We are grateful to the Water Communities Sector (ELHC) of the Environmental Company of the State of São Paulo - CETESB, especially to the biologists Monica Luisa Kuhlmann and Hélio Rubens Victorino Imbimbo. The Coordination of Improvement of Higher Education Personnel (CAPES) for financial support.

\section{References}

ALVES, R.G. and GORNI, G.R., 2007. Naididae species (Oligochaeta) associated with submersed aquatic macrophytes in two reservoirs (São Paulo, Brazil). Acta Limnologica Brasiliensia, vol. 19 , no. 4 , pp. 407-413.

ALVES, R.G., MARCHESE, M.R. and MARTINS, R.T., 2008. Oligochaeta (Annelida, Clitellata) of lotic environments at Parque Estadual Intervales (São Paulo, Brasil). Biota Neotropica, vol. 8, no. 1, pp. 69-72. http://dx.doi.org/10.1590/S1676-06032008000100009.

BEHREND, R.D.L., TAKEDA, A.M., GOMES, L.C. and FERNANDES, S.E.P., 2012. Using Oligochaeta assemblages as an indicator of environmental changes. Brazilian Journal of Biology $=$ Revista Brasileira de Biologia, vol. 72, no. 4, pp. 873-884. http://dx.doi.org/10.1590/S1519-69842012000500014. PMid:23295517.

BRINKHURST, R.O. and JAMIESON, B.G.M., 1971. Aquatic Oligochaeta of the world. Toronto: University of Toronto Press, $860 \mathrm{p}$.

BRINKHURST, R.O. and MARCHESE, M.R., 1989. Guia para la identificación de oligoquetos acuáticos continentales de Sudy Centroamerica. Santa Fé: Asociación de Ciencias Naturales del Litoral, vol. 6, 179 p.

CHRISTOFFERSEN, M.L., 2007. A catalogue of aquatic microdrile oligochaetes (Annelida: Clitellata) from South America. Shui Sheng Sheng Wu Hsueh Bao, vol. 31, pp. 59-86.

COMPANHIAAMBIENTAL DO ESTADO DE SÃO PAULO CETESB, 2003 [viewed 27 September 2017]. CETESB L5.309: determinação de bentos de água doce: macroinvertebrados: métodos qualitativo e quantitativo [online]. São Paulo: CETESB, 16 p. Available from: http://cetesb.sp.gov.br/normas-tecnicascetesb/normas-tecnicas-vigentes/

CORBI, J.J., JANCSO, M.A., STRIXINO, S.T. and FRAGOSO, E.N., 2004. Occurence of Oligochaeta living on larvae of Odonata from Ipeúna (São Paulo state, Brazil). Biota Neotropica, vol. 4, no. 2, pp. 1-3. http://dx.doi.org/10.1590/S1676-06032004000200017.

ESTEVES, F.A., LEAL, J.J.F. and CALLISTO, M., 2011. Comunidade bentônica. In: F.A. ESTEVES, ed. Fundamentos de limnologia. 3. ed. Rio de Janeiro: Interciência, 790 p.

GORNI, G.R. and ALVES, R.G., 2006. Naididae (Annelida, Oligochaeta) associated with Pomacea bridgesii (Reeve) (Gastropoda, Ampullaridae). Brazilian Journal of Biology = Revista Brasileira de Biologia, vol. 23, no. 4, pp. 1059-1061.

GORNI, G.R. and ALVES, R.G., 2007. Naididae (Annelida, Oligochaeta) associated with briophytes in Brotas, State of São Paulo, Brazil. Brazilian Journal of Biology $=$ Revista Brasileira de Biologia, vol. 24, no. 2, pp. 518-519.

GORNI, G.R. and ALVES, R.G., 2008. Naididae species (Annelida: Oligochaeta) associated with the sponge Metania spinata (Carter,
1881) (Porifera: Metaniidae) from a southeastern reservoir. Acta Limnologica Brasiliensia, vol. 20, no. 3, pp. 261-263.

GORNI, G.R., PEIRÓ, D.F. and SANCHES, N., 2015. Aquatic Oligochaeta (Annelida: Clitellata) from State of São Paulo, Brazil: Diversity and Ocurrence review. Biota Neotropica, vol. 15, no. 1, pp. 1-8. http://dx.doi.org/10.1590/1676-06032015006314.

MARCUS, E., 1944. Sobre Oligochaeta límnicos do Brasil. Boletim de Zoologia, vol. 43, no. 8, pp. 5-135.

MARONEZE, D.M., TUPINAMBÁS, T.H., FRANÇA, J.S. and CALLISTO, M., 2011. Effects of flow reduction and spillways on the composition and structure of benthic macroinvertebrate communities in a Brazilian river reach. Brazilian Journal of Biology $=$ Revista Brasileira de Biologia, vol. 71, no. 3, pp. 639-651. http://dx.doi.org/10.1590/S1519-69842011000400008. PMid:21881787.

MONTANHOLI-MARTINS, M.C. and TAKEDA, A.M., 2001. Spatial and temporal variations of oligochaetes of the Ivinhema River and Patos Lake in the Upper Paraná River Basin, Brazil. Hydrobiologia, vol. 463, no. 1-3, pp. 197-205. http://dx.doi. org/10.1023/A:1013163927814.

ODA, F.H., PETSCH, D.K., RAGONHA, F.H., BATISTA, V.G., TAKEDA, A.M. and TAKEMOTO, R.M., 2015. Dero (Allodero) lutzi Michaelsen, 1926 (Oligochaeta: Naididae) associated with Scinax fuscovarius (Lutz, 1925) (Anura: Hylidae) from Semideciduous Atlantic Rain Forest, Southern Brazil. Brazilian Journal of Biology $=$ Revista Brasileira de Biologia, vol. 75, no. 1, pp. 86-90. http://dx.doi.org/10.1590/1519-6984.07613. PMid:25945624.

OLIVEIRA, V.C., GONÇALVES, E.A. and ALVES, R.G., 2014. Colonisation of leaf litter by aquatic invertebrates in an Atlantic Forest stream. Brazilian Journal of Biology $=$ Revista Brasileira de Biologia, vol. 74, no. 2, pp. 267-273. http://dx.doi. org/10.1590/1519-6984.10512. PMid:25166310.

PETSCH, D.K., RAGONHA, F.H., GIMENEZ, B.C.G., BARBOZA, L.G.A. and TAKEDA, A.M., 2015. Beta diversity partitioning of aquatic Oligochaeta in different environments of a neotropical floodplain. Acta Scientiarum, vol. 37, pp. 41-49.

RAGONHA, F.H., PETSCH, D.K., ALVES, G.H.Z., SANTANA, H.S., MICHELAN, T.S. and TAKEDA, A.M., 2014. Tributaries as richness source for Oligochaeta assemblage (Annelida) of Neotropical dammed river. Brazilian Journal of Biology $=$ Revista Brasileira de Biologia, vol. 74, no. 4, pp. 861-869. http://dx.doi. org/10.1590/1519-6984.05613. PMid:25627596.

RIGHI, G., 1984. Manual de identificação de invertebrados límnicos do Brasil. Brasília: CNPQ/Coordenação Editorial.

RODRIGUEZ, P. and REYNOLDSON, T.B., 2011. The pollution biology of aquatic oligochaetes. Dordrecht: Springer Science. http://dx.doi.org/10.1007/978-94-007-1718-3.

TIMM, T., SEIRE, A. and PALL, P., 2001. Half a century of oligochaete research in Estonian running waters. Hydrobiologia, vol. 463, no. 1-3, pp. 223-234. http://dx.doi.org/10.1023/A:1013176229631.

TRIVINHO-STRIXINO, S., CORREIA, L.C.S. and SONODA, K., 2000. Phytophilous Chironomidae (Diptera) and other macroinvertebrates in the ox-bow Infernão lake (Jataí Ecological Station, Luiz Antônio, SP, Brazil). Brazilian Journal of Biology = Revista Brasileira de Biologia, vol. 60, no. 3, pp. 527-535. http:// dx.doi.org/10.1590/S0034-71082000000300018. PMid:11188879. 